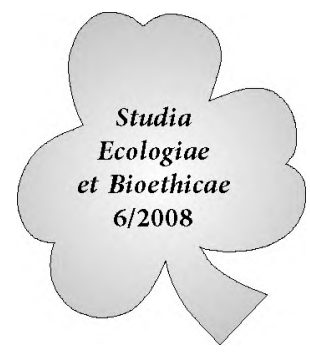

\title{
Promieniowanie słoneczne a witamina $D$ i nowotwory skóry
}

Promieniowanie słoneczne jest częścią środowiska życia człowieka. Aktualnie powszechnie akceptowanym jest fakt, że zarówno niedobór jak i nadmierna ekspozycja na to promieniowanie niekorzystnie wpływa na zdrowie ludzi. W relacjach tych szczególne miejsce zajmuje promieniowanie ultrafioletowe i jego wpływ na syntezę witaminy D oraz wywoływanie niekorzystnych zmian w komórkach organizmu prowadzących do rozwoju m.in. chorób nowotworowych.

Promieniowanie ultrafioletowe (UV), zgodnie z definicją przyjętą przez WHO w 1994 roku, obejmuje promieniowanie o długości fal między $100 \mathrm{~nm}$ a $400 \mathrm{~nm}$. Wyróżnia się promieniowanie typu UVA: 315 - $400 \mathrm{~nm}$, UVB: 280 - 315 nm i UVC: 100 - 280 nm [1]. Obok Słońca, które jest głównym źródłem promieniowania UV, w aspekcie jego wpływu na zdrowie człowieka, istotną rolę odgrywają sztuczne źródła tego promieniowania, na działanie których jesteśmy narażeni w miejscu pracy lub korzystając z solarium. Słoneczne promieniowanie ultrafioletowe działające na organizm człowieka to promieniowanie typu UVA i UVB. Badania eksperymentalne pokazały, że UVB jest niezbędne dla syntezy witaminy D. Jednocześnie to ono jest głównie odpowiedzialne za oparzenia skórny, rozwój nowotworów oraz działanie immunosupresyjne. UVA przez długi okres wiązane było przede wszystkim z procesami starzenia skóry. Obecnie uważa się, że również wpływa na rozwój nowotworów i zaburza przebieg procesów immunologicznych. Dlatego dużą uwagę zwraca się na działanie lamp emitujących ten typ promieniowania i zagrożenia zdrowia, jakie mogą być z tym związane [2].

W ocenie działania promieniowania słonecznego na organizm człowieka nie określa się specyficznych efektów UVA i UVB, lecz ocenia sumaryczny efekt wynikający z ekspozycji na światło słoneczne.

\section{Witamina D - funkcja fizjologiczna}

Kluczową funkcją fizjologiczną witaminy D jest utrzymywanie stężenia wapnia i fosforu w granicach niezbędnych dla prawidłowego przebiegu różnych pro- 
cesów komórkowych, prawidłowego funkcjonowania układu nerwowego i mięśniowego oraz zapewnienia prawidłowej budowy kości [3]. Witamina D wpływa na jelitowe wchłanianie wapnia i fosforu oraz procesy odkładania i uwalniania wapnia $z$ kości. Fizjologiczne działanie witaminy D jest jednak znacznie szersze i wychodzi poza jej rolę w gospodarce składnikami mineralnymi. Witamina D wpływa m.in. na różnicowanie i proliferację komórek, sekrecję insuliny, a także reguluje transkrypcję licznych genów w wyniku wiązania ze specyficznym receptorem jądrowym (tzw. receptor dla witaminy D oznaczany jako VDR) działającym jako czynnik transkrypcyjny. Obecność VDR stwierdzono w komórkach różnych tkanek.

Poziom witaminy D w krążeniu zależy od jej dowozu z dietą oraz poziomu jej syntezy. Dlatego też witamina D nie jest typową witaminą i często nazywana jest hormonem. \o w jakim stopniu jest ona niezbędnym składnikiem odżywczym (a więc składnikiem dostarczanym z dietą) zależy od zdolności organizmu do biosyntezy aktywnej postaci tego związku.

Wyróżniamy dwie formy witaminy D różniące się budowa łańcucha bocznego: ergokalcyferol czyli witaminę D2 i cholekalcyferol czyli witaminę D3. Witamina D2 występuje głównie w organizmach roślinnych a witamina D3 w organizmach zwierzęcych i powstaje w skórze czlowieka pod wpływem promieniowania słonecznego. W organizmie człowieka witaminy D2 i D3 ulęgają przemianom, w efekcie których tworzy się biologicznie aktywna forma witaminy D czyli kalcytriol.

\section{Promieniowanie słoneczne a synteza witaminy D}

W organizmie czlowieka biosynteza witaminy D rozpoczyna się w skórze, gdzie pod wpływem promieniowania UVB następuje konwersja obecnego w błonach komórkowych 7-dehydroksycholesterolu do prowitaminy D, która ulega termicznej izomeryzacji tworząc cholekalcyferol (witaminę D3). Powstała witamina D3 jest uwalniana do przestrzeni pozakomórkowej i wiąże się ze specyficznymi białkami umożliwiającymi jej transport poprzez układ krążenia do wątroby. Do wątroby dociera również witamina D3 jak i D2 pochodząca z diety. W wątrobie zachodzi proces hydroksylacji tych związków i powstaje 25-OH-D3. Następnym etapem jest transport tego związku do nerek i jego ponowna hydroksylacja prowadząca do powstania kalcytriolu będącego kluczową formą witaminy D wykazującą wysoką aktywność biologiczną. Produkcja kalcytriolu jest regulowana przez stężenie wapnia we krwi oraz stężenie parathormonu i ściśle związana $z$ homeostazą wapnia. Ilość 25-OH-D3 warunkuje możliwość tworzenia biologicznie aktywnej postaci witaminy $D$, ale nie jest głównym czynnikiem determinującym jej poziom. Stężenie 25-OH-D3 kilkakrotnie przewyższa stężenie kalcytriolu i jest uważane za wskaźnik pokrycia zapotrzebowania na witaminę $\mathrm{D}$. 
Poziom ekspozycji na światło słoneczne determinuje poziom syntetyzowanych w skórze form witaminy D. Zależy on od takich czynników środowiskowych jak szerokość geograficzna, pora roku, pora dnia, zawartość ozonu, poziom zachmurzenia, a także cech osobniczych jak typ skóry, wiek, sposób ubierania się, zwyczajowy czas przebywania na otwartej przestrzeni, używanie preparatów zawierających filtry promieniowania. Niska ekspozycja na światło słoneczne wiąze się z niskim poziomem biosyntezy witaminy D. Jednak nadmierna ekspozycja powoduje szybką dalszą fotoizomeryzację syntetyzowanych w skórze związków i powstawanie form nie wykazujących aktywności biologicznej.

Pigmentacja skóry jest ważnym czynnikiem determinującym ilość promieniowania docierającego do komórek. Melanina ma bowiem zdolność absorpcji promieni UV i w ten sposób chroni komórki przed nadmiernym działaniem tego promieniowania. Dlatego populacje narażone na silne działanie promieniowania słonecznego mają ciemną skórę stanowiąca naturalną barierę dla tego promieniowania. Natomiast populacje żyjące na obszarach o niskim nasłonecznieniu charakteryzuje bardzo jasny kolor skóry [4].

Wykazano, że na obszarach o niskim nasłonecznieniu w pewnych okresach poziom promieniowania UVB jest tak niski, że nie aktywuje biosyntezy witaminy D. \aka sytuacja ma miejsce m.in. na obszarze Bostonu w miesiącach zimowych. Natomiast na innych obszarach, np. w okolicach Los Angeles czy Puerto Rico, stopień nasłonecznienia zapewnia indukcję tej biosyntezy o każdej porze roku $[5,6]$.

Ponadto ekspozycja na promieniowanie UVB głowy, ramion i rąk przez 20 minut powoduje syntezę takiej samej ilości witaminy D co ekspozycja całego ciała przez okres 2 minut [7]. Krótkotrwała ekspozycja dużych powierzchni skóry jest więc bardziej efektywna ze względu na syntezę witaminy D niż długotrwała ekspozycja małych obszarów i jednocześnie wiąże się z mniejszym ryzykiem oparzeń i uszkodzeń skóry przez promieniowanie UV, zwłaszcza, że długotrwałe działanie UV poprzez dezaktywację powstałych związków (o czym wspominano powyżej) nie dopuszcza to przekroczenia określonego poziomu syntezy tej witaminy. Uzyskanie prawidłowego poziomu syntezy witaminy D nie wymaga uzyskania efektu opalenizny.

Ubranie oraz preparaty kosmetyczne zawierające filtry UV stanowią barierę dla promieniowania UV i w ten sposób ograniczają jego ilość docierającą do komórek skóry i wpływają na możliwość stymulacji biosyntezy witaminy D. Ocenia się, że prawidłowe stosowanie preparatów typu SPF 15 może redukować poziom syntezy witaminy D o $99 \%$ [2].

Witamina D należy do witamin rozpuszczalnych w tłuszczach i tkanka tłuszczowa jest miejscem przechowywania witaminy powstałej w okresie odpowiedniej ekspozycji na światło słoneczne, co umożliwia jej wykorzystanie w okresie redukcji biosyntezy. Regularna wysoka synteza witaminy D w okresie letnim 
zapobiega występowaniu niedoborów tej witaminy na obszarach niskiego nasłonecznie zwłaszcza w okresie zimy. Jednocześnie należy pamiętać, że dieta jest również ważnym źródłem witaminy D i w istotny sposób wpływa na stan odżywienia tą witaminą, co szczególnie uwidacznia się w populacjach żyjących na obszarach powyżej 50-tego równoleżnika [5].

\section{Niedobór witaminy $D$}

Głównymi przyczynami niedoboru witaminy D są: niska biosynteza i niski dowóz tej witaminy z dietą. Wzrost spożycia witaminy D jest kluczowym elementem działań mających na celu zapobieganie niedoborom tej witaminy.

Choroby nerek czy choroby wątroby ze względu na rolę tych narządów w formowaniu biologicznie aktywnej postaci witaminy D mogą w istotny sposób determinować stan odżywienia tą witaminą. Zaburzenia wchłaniania mogą także powodować jej niedobory.

Niedobór witaminy D zaburza wchłanianie wapnia i odkładanie wapnia w kościach, co znajduje swój wyraz w rozwoju takich chorób jak krzywica i osteoporoza. Ze względu na szerokie działania fizjologiczne witaminy D, jej niski poziom wiąże się z rozwojem nadciśnienia tętniczego i chorób układu sercowo-naczyniowego, sprzyja rozwojowi chorób o podłożu autoimmunologicznym, a także zwiększa ryzyka rozwoju m.in. nowotworów jelita grubego, prostaty, sutka, jajnika [4,8-11].

\section{Promieniowanie słoneczne a nowotwory skóry}

Liczne obserwacje udokumentowały, że zwiększona ekspozycja na promieniowanie UV wiąże się ze wzrostem ryzyka nowotworów skóry, nowotworów warg, a także wielu chorób oczu w tym katarakty [12]. Międzynarodowa Agencja do badan nad Rakiem uznała promieniowanie UV za ważny czynnik kancerogenny. Mutagenne działanie tego promieniowania zostało dobrze udokumentowane. Badania epidemiologiczne pokazały, że osoby o jasnym kolorze skóry, włosów i oczu są bardziej narażone na szkodliwe działanie promieniowania słonecznego niż osoby o ciemnej pigmentacji. Związek między poziomem ekspozycji na promieniowanie słoneczne i rozwojem różnego typy nowotworów jest zależnością złożoną i być może zależy w większym stopniu od charakteru i okresu ekspozycji niż średniej ekspozycji na to promieniowanie. Zaobserwowano, że nowotwory skóry częściej występują u osób u których dochodziło do oparzeń skóry w wyniku krótkotrwałej ale intensywnej ekspozycji, a także u osób które w okresie dzieciństwa były narażone na intensywne działanie promieniowania słonecznego, mimo że później żyły na obszarach o niskim nasłonecznieniu. Promieniowanie UV jest przyczyną ponad 90\% nowotworów typu melanoma 
w Ameryce Północnej, Europie Północnej a także w Australii [13]. Ponadto częstość tych nowotworów jest wyższa w populacjach rasy białej mieszkających na obszarach o dużym nasłonecznieniu w porównaniu z populacjami tej rasy zamieszkującymi obszary o małym nasłonecznieniu. Ochrona przed nadmierna ekspozycja na promieniowanie UV jest kluczowym elementem działań mających na celu zapobieganie rozwojowi przede wszystkim nowotworów skóry oraz części chorób oczu.

\section{Zalecenia dotyczące ekspozycji na promieniowanie ultrafioletowe}

Promieniowanie słoneczne jest niezbędnym elementem zapewniającym prawidłowy rozwój i działanie organizmu człowieka. Jednocześnie nadmierna ekspozycja na promieniowanie UV jest przyczyną rozwoju przede wszystkim nowotworów skóry.

W oparciu o liczne dane dotyczące oddziaływania promieniowania słonecznego na organizm człowieka, Swiatowa Organizacja Zdrowia opracowała wytyczne w zakresie prewencji nadmiernej ekspozycji na promieniowani UV [14]. Zalecenia te wskazują na konieczność:

- limitowania czasu ekspozycji słoneczne poprzez ograniczenie narażenia na promieniowanie zwłaszcza w godzinach południowych, między godzinami 10 a 14, kiedy to obserwuje się najwyższe natężenie promieniowania UV

- przebywania w miejscach zacienionych w okresie największego natężenia promieniowania

- ochrony skóry poprzez stosowanie odpowiedniego ubrania oraz preparatów zawierających SPF 15+

- ochrony oczu poprzez stosowanie odpowiednich okularów przeciwsłonecznych

- unikania sztucznych źródeł promieniowania UV: lamp i łóżek opalających

- zwracania szczególnej uwagi na ochronę dzieci przed szkodliwym działaniem promieniowania UV

Jednocześnie zwraca się uwagę, że ilość promieniowania UVB niezbędna dla prawidłowej biosyntezy witaminy D nie wymaga uzyskania efektu opalenizny. Kilkuminutowa regularna ekspozycja ciała na promieniowanie słoneczne w godzinach przed lub popołudniowych jest wystarczająca dla uzyskania odpowiedniego poziomu tej witaminy. Ponadto witamina $\mathrm{D}$ powinna być dostarczana $z$ dietą i prawidłowo skomponowana dieta jest naturalnym sposobem zapobiegania jej niedoborom. Ponadto w przypadku populacji narażonych z różnych przyczyn na niedobory witaminy D należy rozważyć zasadność jej suplementacji, nie należy zaś propagować nadmiernego wzrostu ekspozycji na promieniowanie słoneczne ze względu na udokumentowane działania nieporządne promieniowania ultrafioletowego. 


\title{
LI冈ERA囚URA
}

1. WORLD HEALXH ORGANIZADION (WHO).Environmental Health Criteria No.160, Ultraviolet Radiation Joint Publication of the United Nations Environmental Program, The International Radiation Protection Association and World Health Organization. WHO, Geneva 2004

2. REICHRAFDH J. The challenge resulting from positive and negative effects of sunlight: how much solar UV exposure is appropriate to balance between risk of vitamin D deficiency and skin cancer? Progress in Biophysics \& Molecular Biology 2006, 92:9-16

3. SU冈冈ON A, MACDONALD P. Vitamin D: more than a "bone-a-fide" hormone. Molecul. Endocrinol. 2003, 17:777-791

4. HOLICK M.F. The vitamin D epidemic and its health consequences. J.Nutr. 2005, 137: 2739S$-2748 \mathrm{~S}$

5. WEBB A.R, KLINE L, HOLIC M.F. Influence of season and latitude on the cutaneous synthesis of vitamin D, exposure to winter sunlight in Boston and Edmonton will not promote vitamin D synthesis in human skin. J. Clin.Endocrinol.Metab. 1988, 67:373-378

6. SLINEY D.H, WENGRAIXIS S. Is a differentiated advise by season and region necessary? Progress in Biophysics \& Molecular Biology 2006, 92:150-160

7. WEBB A.R. Who, what, where and when - influences on cutanous vitamin D synthesis. Progress in Biophysics \& Molecular Biology 2006, 92:17-25

8. HOLICK J.M. Vitamin D. Importance in the prevention of cancers, type 1 diabetes, heart disease and osteoporosis. Am. J. Clin. Nutr. 2004, 79:362-371

9. GRANQ W.B. An estimate of premature cancer mortality in U.S. due to inadequate doses of solar UVB radiation. Cancer 2002, 94:1867-1875

10. PONSONBY A.L, MCMICHAEL A, VAD DER MEI I. Ultraviolet radiation and autoimmune disease: insight from epidemiological research. \oxicology 2002, 181/182:71-78

11. NORMAN P.E, POWELL J.凹. Vitamin D, shedding light on the development of disease in peripheral arteries. Arterioscler Thromb Vasc Biol. 2006, 25:39-46

12. GALLAGHER R.P, LEE $\triangle . K$. Adverse effects of ultraviolet radiation: a brief review. Progress in Biophysics \& Molecular Biology 2006, 92:119-131

13. Armstrong B.K, Kricker A. How much melanoma is caused by sun exposure? Melanoma Res. 1993, 3:395-401

14. WORLD HEAI冈H ORGANIZA囚ION (WHO):_www.who.int (Sun protection, Global disease burden from solar ultraviolet radiation, Global solar index, Protecting children from ultraviolet radiation, The known health effects of UV)

\section{Solar radiation: vitamin $\mathrm{D}$ and skin cancer}

\author{
SUMMARY
}

Solar radiation is a part of the environment of man. Ultraviolet B radiation in required for the biosynthesis of vitamin $D$, which is generally associated with calcium metabolism and significantly influences a wide range of metabolic systems, therefore, has a strong influence on human health. However, exposure to sunlight carries potential risks to human health. Ultraviolet radiation is a known carcinogen and excessive sunlight exposure significantly increases risk of skin cancer. 